\title{
AN INVESTIGATION OF INDUSTRY EXPECTATIONS OF INDUSTRIAL ENGINEERING GRADUATES: A CASE STUDY OF GRADUATE DEVELOPMENT PROGRAMMES IN SOUTH AFRICAN UNIVERSITIES
}

\author{
W.K. Ngetich ${ }^{1 *} \&$ C.M. Moll ${ }^{2}$ \\ ${ }^{1}$ Department of Industrial and Systems Engineering \\ Cape Peninsula University of Technology, South Africa \\ ngetichw@cput.ac.za \\ ${ }^{2}$ Department of Industrial and Systems Engineering \\ Cape Peninsula University of Technology, South Africa \\ MollCM@cput.ac.za
}

\begin{abstract}
During 2008 and 2009, post-apartheid South Africa and the global community experienced maj or economic turbulence, bringing into focus the need for skills development across the major South African economic sectors to resuscitate its failing economy. The solutions lay in organisations re-evaluating their current operational strategies by streamlining their organisations, and adopting aggressive, lean, and cost-saving approaches to remain competitive. The study introduced the need to address this issue by exploring the environments that play a role in the quality of life in South Africa. A qualitative and quantitative data collection and analysis approach was used to establish the skills gap between the business market and training institutes, in an effort to alleviate the negative effects of the current state of the economy. The need for skills growth and for cost-cutting, cost-saving, and an optimisation skill - a skill descriptively and applicably seen in industrial engineering - is apparent. The role of graduate institutions in facilitating the growth of human capital development in the work environment has become a critical factor in South Africa, aimed at improving the productivity and economic growth of the country. In this paper, the focus is on three main areas of discussion: the institutional environment of students; exploring the student-lecturer relationship; and the work environment. The study highlights the influence these three environments have on industrial engineering skills and competencies attained by industrial engineering university student graduates, and how this ultimately creates a way for the South African economy to grow.
\end{abstract}

\section{OPSOMMING}

Post-apartheid Suid-Afrika, asook die res van die wêreld, het gedurende 2008 en 2009 groot ekonomiese druk ervaar met armoede, werkloosheid, en vaardigheidstekorte wat tot lae produktiwiteitsvlakke en afskaling in arbeid gelei het. Die regering en die sakesektor het as gevolg hiervan herbesin oor vaardigheidsontwikkeling in die belangrikste sektore van die ekonomie. Die oplossing was dikwels geleë in die bedryfstrategieë van organisasies, en daarom is daar veral op bedryfsvlakke gelet op vaartbelyning, kostbesparing, en verskralingsmetodes ten einde kompeterend te bly. Twee faktore het duidelik geraak: die behoefte aan vaardigheidsontwikkeling, en die behoefte aan kostebesparing en optimisering. Hierdie vaardighede is beskrywend en tiperend van bedryfsingenieurswese. Die rol van tersiêre instansies in die uitbreiding van vaardighede is ook ' $\mathrm{n}$ kritieke faktor in Suid-Afrika, gerig op die verbetering van produktiwiteit en ekonomiese groei. Hierdie artikel fokus op hierdie belangrike areas, en ondersoek veral die rol van bestaande student, dosente, en bedryfspraktisyns. Die studie wys die rol van hierdie rolspelers uit en hoe hulle saam ' $n$ positiewe rol in die Suid-Afrikaanse ekonomie kan speel.

\footnotetext{
*Corresponding author
} 


\section{$1 \quad$ INTRODUCTION}

Since the 1970s and 1980s, skills development has been, and still is, a contentious issue in the South African industrial sector. The skills shortage in South Africa is one of the main impediments to reaching the government's stated economic growth targets. This has made skills development crucial to South Africa's growth and progress [10]. Two maj or challenges addressed during the post-apartheid era, poverty and unemployment [24], called for an aggressive approach to skills development. This aggressive approach is evident in the government's efforts in creating the Department of Higher Education and Training. This has incorporated various entities, such as human capital development, under the Human Resource Development Strategy for South Africa and the higher education bodies, in cooperation with the South African Qualifications Authority, to foster skills development that aims to realise a systematised post-school education and training structure.

The South African Qualifications Authority Act [19,25], passed into law in October 1995, prescribed the establishment of, among other entities, the South African Qualifications Authority, the National Qualifications Framework, and the Sectoral Education and Training Authorities. The introduction of the J oint Initiative for Priority Skills Acquisition, together with the higher education bodies, has created a renewed approach to the economic skills needed to improve economic growth, as reaffirmed by Mlambo-Ngcuka:

'In a country such as ours skills shortage and skills inadequacy is so glaring. In South Africa we have missed so many opportunities because of skills. We import artisans, welders even for regular scheduled activities such as statutory shutdowns of oil refineries. Concurrently we also need a skills revolution in the curriculum of tertiary education, as well as in the quality of public education. In identifying growth areas in our economy we have isolated the growth and areas in which inadequate service provision, constrains growth. These are: infrastructure limitation; sectoral development; economy initiatives; service delivery; and Human Resource Development (HRD), the biggest cross-cutting constraint. Since the issue of appropriate skills arises as the most constraining factor. In AsgiSA, we have established the Joint Initiative for Priority Skills Acquisition (JIPSA) as an interim response to deal with skills shortages. The skills that we lack and desperately need are: engineering skills (100 000 per annum); planning and management skills, and education and health managers; artisans; teacher in public education (in mathematics and science), the inability to communicate by graduates has been identified by employers as a maj or problem that contributes to the unemployment of graduates; cross-cutting skills; Information and Communication Technology (ICT); project managers; finance skills; skills for growing sectors e.g. ICT.' [10]

The evolution of industrial engineering, as discussed by Zandin [36], began in the early 1960s with the learning 'student' being equipped with subjects such as work-study, method studies, production, material handling, layout planning, and a few financial subjects. During the 1970s it was realised that the environment of industrial engineers was changing, and that the student was entering an era of planning and scheduling. As a result, the academic syllabi changed, and the inclusion of additional subjects like control systems, material science, operations research, statistical quality control, and computers and programming was necessary. Industrial engineers began to emerge as engineers trained to see the 'bigger picture' in a systems perspective. It was also realised that these engineers could perform outside the arena of hard production and enter the world of service sectors [38]. According to Statistics South Africa [29], in 2008 and 2009 South Africa underwent a trying economic slump, losing a maj or percentage of its manufacturing labour force. As a result, most manufacturing firms relied on re-evaluating their operational strategies by undertaking leaner and more aggressive cost-saving approaches to keep their competitive edge. This signalled a revival for the industrial engineering field as most companies delved into streamlining their organisations, employing industrial engineering practices and techniques such as six sigma and continuous improvement, and taking on industrial engineering professionals. Industrial engineering was slowly gaining attention as a way of 
cutting costs and maintaining a cost-effective business approach. This created a niche for industrial engineering as a much-needed value-adding component for business excellence.

Industrial engineering is a necessary skill in any developing and developed country. The need is evident in the increase in cost-saving approaches that South African companies employ. This study explores the correlation between industry skills expectations and the academic ability to meet this need. The study needed to satisfy the researchers' enquiry into the relationship between the quality of graduating South African industrial engineers who are actually employed within the relevant job market, and the expected growth. In addition, the needs of the job industry are expected to be met by the various learning institutions (universities in this case), placing a responsibility on both the industry and the universities to ensure that students learn what is relevant and useful for job performance and development. It is thus imperative to investigate this relationship between industry and graduate industrial engineers, with an emphasis on the government's skills expectations, and on the academic capacity to meet these skills expectations in today's competitive professional arena, as noted by Nel [13].

The economic strain experienced by the South African economy leads this study to question whether there is a lack of adequate communication between industry and institutions, resulting in the skills level and academic qualification attained by graduating industrial engineers not meeting industry expectations. In making this statement, we are in fact asking ourselves the following: "Are graduate industrial engineers able to meet the minimum demands and skills level expected by the relevant industrial engineering industry?" In answering this question, several objectives are defined and further explored to highlight the gap between the students' skills level acquired from academic knowledge, and the application of this skill within the industrial engineering environment. The objectives for this study are as follows:

- to determine the significant roles played by industrial engineering graduates in industry;

- $\quad$ to identify the minimum skills level of an industrial engineering graduate;

- to identify the existing academic national qualification framework for industrial engineering curricula, as defined by the South African Qualifications Authority; and

- to define effective mechanisms to ensure levels of high quality industrial engineering graduates who are capable of meeting industry expectations.

\section{LITERATURE REVIEW}

Since 1994 the skills shortage in South Africa has been a concern, triggering various discussion forums in an effort to understand and articulate its dynamics and its impact on economic development $[26,30]$. It is important to understand organisations in an economic context as a value model, towards the successful execution of organisational strategy in satisfying customer needs. The view of quality in industrial engineering exists in two distinct paradigms; the perceived value of the programme, and the characteristics inherent within the industrial engineering skill. These are relatively synonymous with the delivery process of quality commonly applied in any system.

The industrial engineering programme in global institutions of higher learning strives to create innovative, current, and knowledge-driven engineering programmes that have considerable industry value. Here we discuss this value not only as influencing economic growth, but also as playing a significant role in increasing the level of throughput within the respective academic institutions [6]. .

\subsection{Skills level and the significant role of industrial engineering in productivity}

Poverty, inequality, and unemployment are under debate, with the scarcity of skills being particularly relevant [30]. South Africa [28] demonstrates that income inequalities in the various sectors of industry play a major role in the skills shortage. Results obtained from the 2005/ 6 income and expenditure survey [26] reveal a gap between the various income 
earners in industry. The results show that 10 per cent of the population earns more than 50 per cent of household income, while 80 percent of the population earns less than 8.5 per cent of the household income. This negates the need for skills as a source of income [26]. In addition, the unusually high unemployment rate manifests itself in a low youth count in the labour market and the education and training system [4]. The poor and ineffective educational outcome is evident in the poor results in the latest annual national assessments literacy and numeracy levels [31].

This challenge calls for a more effective approach to the education of proficient graduates and a balance between supply and demand if there is to be improved socio-economic growth and development. Articulation of the link between the education sector and industry creates a platform for the development of quality programmes in the education sector that cater directly to the needs of industry [23,32]. The National Industrial and Policy Framework of the Department of Trade and Industry (DTI) states that "...the skills and education system forms a fundamental pillar for the success of an industrial policy. There is currently insufficient integration between industrial policy objectives and skills in the education system. There is therefore a need for a much closer alignment between industrial policy skills and education development, particularly with respect to sector strategies..." [27]. In the light of these revelations of inequality and poor schooling outcomes, an understanding of the importance of effective post-school and supportive training systems is worth exploring, to improve South Africa's developmental growth and sustainability.

Industrial engineering is a branch of engineering that focuses skills knowledge towards effective systems development and optimisation in both product engineering and service related fields [38]. In the South African engineering context, industrial engineering is a skill represented in the following disciplines: industrial technologists, industrial technicians, and industrial professional engineers [20,21]. The Department of Home Affairs listed industrial engineering as a national scarce and critical skill in 2006, substantiating the need for industrial engineering as a highly sought-after skill [27]. According to Nel and MulabaBafubiandi [12], the number of professionally registered South African engineers in the engineering database in 2006 was 5,000 engineers, 1,600 technologists, and 6,700 technicians; and in March 2005 there were only 225 registered industrial engineers.

In 2008 the Southern African Institute for Industrial Engineering stated that the varied characteristics of the industrial engineering profession had shifted beyond the conventional engineering applied in the manufacturing sector before 1950, and had widened to feature in non-manufacturing areas that include consulting, banking, healthcare, and government [12]. An article in Business Times in March 2007, cited by Project 2010 [15], stated that "...companies are buckling under the increasing demands of a growing economy and in the face of fierce competition from international businesses, companies 'creaking under the strain' of a 'skills crisis' and the need to deliver bigger volumes of goods to increasingly diverse customers. This is compromising SA's global competitiveness and is spurring "poorer' service across various industries"..." due to the shortage of skills in engineering, supply chain management, warehousing and distribution, and network analysts...". All these skills are relevant to industrial engineering [15]. In addition, the SAlIE industry forum [16] estimates that about 1,000 industrial engineers are needed every year to meet this level of industrial engineering demand for South Africa.

\subsection{Curriculum requirements and skills level}

Industrial engineering focuses on business efficiency - or more precisely, on how to design, organise, implement, and operate the basic factors of production and manufacturing (materials, equipment, people, information, and energy) in the most efficient manner possible. The typical focus is on optimising industrial manufacturing operations, although the skills learned are applicable to other non-manufacturing settings [33]. The list below highlights typical areas an industrial engineer must address, both in academia and for the relevant linked industry skills: 
- Numeracy, advanced mathematics, and sciences (aimed at a comprehensive knowledge of various science and maths dynamics).

- Engineering mechanics, and circuits and electronics (aimed at engineering maintenance and electrical knowledge).

- Computer science and computation (focusing on modelling, simulation, and systems analysis).

- Stochastics (focusing on systems analysis).

- Robotics.

- Politics and economics.

- Ergonomics/human factor engineering (designing the workplace to accommodate 'human factors' (human abilities and behaviours) better, thereby yielding more efficient operations and fewer accidents or injuries).

- $\quad$ Facility design (aimed at operational efficiency).

- $\quad$ Engineering design (aimed at product design and life cycle changes).

- Applied statistics (using statistics and other forms of data analysis to aid in making management decisions and analysing work).

- Manufacturing engineering (concerned with all aspects of manufacturing operations including materials, parts, equipment, facilities, labour, finished products, and delivery).

- Quality control (using sampling, statistical analysis, and other techniques to assess and maintain the quality of products or services provided by a business or other organisation).

- Work design (defining jobs that individual workers do in performing the overall work of the organisation, with the typical focus being on optimising manufacturing operations).

- Worker productivity (conducting time and motion studies, setting work performance standards, and proposing new/ improved work methods).

- Material sciences.

In defining the various roles of industrial engineering fields, the following main industrial engineering disciplines stand out [38]:

- Enterprise engineering: This is the engineering of enterprises as a whole, which evolved from systems engineering. In order to achieve this, industrial engineers make use of their ability to apply knowledge, principles, and disciplines related to the analysis, design, implementation, and operation of all elements associated with an enterprise.

- $\quad$ Systems engineering: This is the approach to designing, creating, and operating systems. It entails identifying and quantifying system goals, with the aim of integrating the needs of each related subsystem to fit the purpose of the main system. The need arose with increased system complexity, poor subsystem integration, and subsequently unstable system reliability.

- Operations management: Operational industrial engineering focuses on designing and improving operations and activities related to the functions delivered by the system role players. One such area is the supply-chain management operation, which aims to link the organisation's role players internally and externally in the system.

- $\quad$ Applied industrial engineering: This is the application of industrial engineering in specific industries. These industries may be dictated to by national economic growth needs. In South Africa, current industrial needs fall under production and productivity growth.

- Engineering management: This is a specialised form of management that is concerned with the application of engineering principles to business practice. Engineering management is a career that brings together the technological, problem-solving, practical understanding of engineering and the organisational, administrative, and planning abilities of management to oversee complex enterprises from conception to completion. 


\subsection{Curriculum development, quality assurance, and academic qualification levels of industrial engineering}

The higher education bodies that were responsible for developing the industrial engineering curriculum were tasked to formulate, standardise, and monitor the current and emerging academic and non-academic qualifications. They found a way to focus the skills level to be more productive. These bodies are the South Africa Qualifications Authority (SAQA) and the Engineering Council of South Africa. Another important body not included among the statutory higher education bodies is the Southern African Institute for Industrial Engineering (SAllE). As the name implies, SAllE is made up of industrial engineers from various disciplines who draw on specialised knowledge and skills in the mathematical, physical, behavioural, economic, and management sciences, focused on finding the best practical solutions that will contribute to the success, prosperity, and creation of wealth in the Southern African economy. SAllE aims to be a vibrant, learned society, representing and promoting all industrial engineers while maintaining a high standard for all South African industrial engineers [17].

The academic qualifications currently attainable by an industrial engineer in South Africa are:

- $\quad$ National Diploma in Industrial Engineering (NQF level 6);

- Bachelor of Technology in Industrial Engineering (NQF level 7);

- $\quad$ Master of Technology in Industrial Engineering (NQF level 9);

- Doctor of Technology in Industrial Engineering (NQF level 10);

- $\quad$ Bachelor of Engineering in Industrial Engineering (NQF level 8);

- Master of Engineering Science: Engineering Management (NQF level 9); and

- Doctor of Engineering (NQF level 10).

This study looks at the alignment of two components - curriculum requirements and the skills level of the graduate industrial engineer - in order to narrow the gap between the student's skills level acquired from academic knowledge, and the application of this skill in the industrial engineering environment.

\subsection{Quality and total quality management in industrial engineering}

Trends in Public Higher Education in South Africa: 1995 to 2004 [22] sets out the number of learners who have successfully graduated during the period 1995-2004, and the number of qualifications registered since the inception of the outcomes-based National Qualifications Framework initiative. The report defines a National Higher Diploma in Industrial Engineering as a qualification at NQF level 6, which will serve as a reference point throughout this study. As mentioned previously, the outcomes-based accreditation of undergraduate engineering programmes has been under discussion since the mid-1900s [9]. The accreditation emphasises the need to produce graduates who adequately meet the needs of industry. It is therefore important to explore whether the outcomes of such engineering programmes do indeed match the needs of industry [5,9]. It is also important to mention that the alignment of the curriculum requirements and the skills level of the graduate industrial engineer is of no consequence if value is not created.. The study proceeds to offer an effective mechanism to ensure high quality levels in industrial engineers who are capable of meeting industry expectations, through a cross-section study of what it means to have quality represented in industrial engineering.

Total quality management is a philosophical management approach developed by several management professionals. One of these was the quality 'guru' W. Edward Deming, who showed how to implement quality improvement through his fourteen points. Organisations, which may include institutions of higher learning, use total quality management to implement quality policies and objectives through directing and controlling a set of integrated elements, in order to achieve a high level of overall operational excellence. Deming's fourteen points were further developed into seven effective concepts; continuous 
improvement, six sigma, employee empowerment, bench-marking, just-in-time, Taguchi concepts, and knowledge of the total quality management tools [35].

J ust as any other organisation that uses quality to gain optimum throughput through total quality management, higher education also requires a quality component. Viewing industrial engineering in institutions of higher learning as a system with interrelated components, with the 'customer' being the product of interest such as the graduate industrial engineer, quality becomes an aspect that cannot be ignored, just as in any other manufacturing process. Chikumba [3] states that the organisational transformation model emphasises that understanding organisations as a model is important for the successful execution of corporate strategy, and that viewing the organisation as a transformation process that satisfies customer needs through maximising value - added to inputs producing outputs through routine and repetitive or programmable decisions - is important. In defining value, the dimensions of quality should not be ignored; value accrues through the creation of the product's function. This ideology is better described mathematically as:

$$
\begin{aligned}
V A L U E & =\frac{\text { FUNCTIONALITY (as a Product or Service or System) }}{\text { COST }} \\
\therefore V A L U E & =\frac{\text { QUALITY, SPEED, and FLEXIBILITY (Drivers of value) }}{\text { RISK, WASTE, and CASH FLOW (Drivers of value) }}
\end{aligned}
$$

Figure 1: Operational value drivers [11]

The three main groups that are considered in this paper and that are responsible for creating this value are found within three domains; industry, institutions of higher learning, and the student. This study, in addition to exploring the gap highlighted earlier, measures the groups against the effectiveness and efficiency model [11]. Being effective gives an individual the ability to achieve a task, given certain pertinent tools and resources. However, achieving the task in the shortest time and with the least effort depends on how efficient one is (Figure 2).

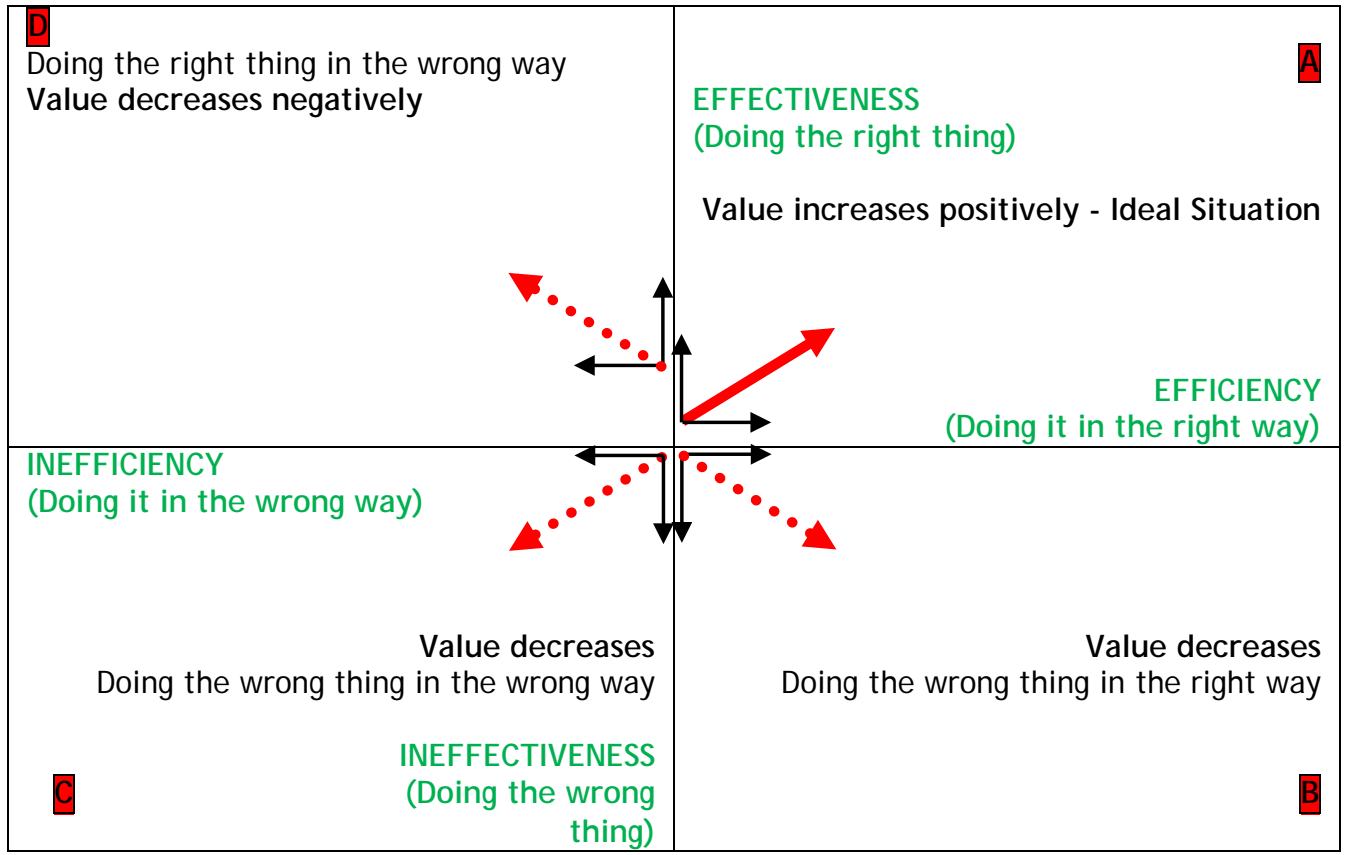

Figure 2: Efficiency and effectiveness: Value [14] 


\section{PROBLEM STATEMENT}

There is a need to investigate the relationship between industry and graduate industrial engineers - a relationship emphasised by the skills expectations addressed by the government, and dependent upon the academic capability to meet these skills expectation. The problem statement is therefore as follows: "There is a lack of adequate communication between industry and institutions, as a result of which the skills level and academic qualification attained by graduating industrial engineers do not meet industry expectations."

The research question statement is thus: "Are industrial engineering graduates able to meet the minimum demands and skills levels expected by the relevant industrial engineering industry?" This led to the following set of investigative sub-questions, which explore the relationship between the minimum level of skills and qualification expected of a graduating industrial engineer by the relevant industrial engineering companies and businesses in South Africa:

- What significant roles are played by industrial engineering graduates in industry?

- What is the minimum skills level for graduate industrial engineers?

- What is the existing academic national qualification framework for industrial engineering curricula, as defined by SAQA?

- How are quality levels ensured for industrial engineering graduates in meeting industry expectations?

\section{RESEARCH METHODOLOGY}

The statistical inferences are drawn from three Likert-type scale questionnaires [2] using a sample group of 154 participants from all three groups (students, lecturers, and the industry). The questionnaires are in the form of an online and a manual survey in conjunction with several interview sessions $[1,8]$. Three separate questionnaires were developed, similar in design and nature, one for each subgroup [1]. A distinction per questionnaire was intentionally built in through re-structuring each survey according to the environment suitable to the sub-group in question. Each questionnaire was divided into three distinct sections covering three prescribed environments of industrial engineering: first, the academic environment, seeking insight into knowledge understanding and creation; second, the industrial/work environment, seeking insight into industrial engineering's impact on the business organisation; and third, the quality environment of industrial engineering, investigating the perceived level of 'value' as understood in this engineering skill.

Depicted below is the study's data-sampling frame:

Table 1: Actual data-sampling frame

\begin{tabular}{|l|l|l|}
\hline Organisation & Sub-group & $\begin{array}{l}\text { Sample size } \\
\text { (n) }\end{array}$ \\
\hline \multirow{2}{*}{$\begin{array}{l}\text { University of Stellenbosch } \\
\text { (academic university) }\end{array}$} & Lecturers & 3 \\
\cline { 2 - 3 } $\begin{array}{l}\text { University of Pretoria } \\
\text { (academic university) }\end{array}$ & Middle to exit level students & 20 \\
\hline $\begin{array}{l}\text { University of J ohannesburg } \\
\text { (university of technology) }\end{array}$ & Lecturers & 3 \\
\cline { 2 - 3 } $\begin{array}{l}\text { Cape Peninsula University of } \\
\text { Technology (university of technology) }\end{array}$ & Middle to exit level students & 20 \\
\hline \multirow{2}{*}{ Industry representatives } & Lecturers & 3 \\
\cline { 2 - 3 } & Middle to exit level students & 3 \\
\cline { 2 - 3 } & Middle to exit level students & 20 \\
\hline & $\begin{array}{l}\text { South African Institute of Industrial Engineers } \\
\text { (SAllE) }\end{array}$ & 65 \\
\cline { 2 - 3 } & Engineering Council of South Africa (ECSA) & 2 \\
\hline
\end{tabular}


The data sampled in the study was analysed using a spreadsheet application designed and created by Del Siegle in Microsoft's Excel programme [18]. The statistical tests were:

- Descriptive statistics with univariate graphs.

- Cronbach's Alpha for reliability testing.

\section{RESULTS}

\subsection{Descriptive statistics}

\subsubsection{Overall analysis of student responses}

The following is a summary of the analysis of student responses, based on a significant percentage response and related to discussions in the literature review and the investigative sub-questions highlighted in the study:

- Role of industrial engineering in industry: The study asked whether students understand and are passionate about industrial engineering and its role in industry. 90 per cent of students answered positively. However, a significant 77 per cent and above are uncertain about its origin, their awareness about it, or its future role in industry.

- Significance of industrial engineering in industry: 88 per cent of students agreed that industrial engineering plays a significant role in industry.

- Minimum skills level of a qualified graduate industrial engineer: 88 per cent of students agreed that a minimum requirement for industrial engineering in industry is a bachelor's degree.

- Knowledge of the SAQA qualification framework for industrial engineering: 76 per cent of students were aware of, knowledgeable about, and understood the workings and interpretations of the National Qualification Framework.

\subsubsection{Effectiveness of students:}

A significant percentage of students agreed that they receive adequate teaching material and effective teaching, including support from tutors and from industry interactions that enhance the quality of the skills taught. Discussion groups, family, and departmental interventions help to enhance their skills and meet any challenges students may face in understanding the industrial engineering programme. 33 per cent of students agreed that interactions with the Engineering Council of South Africa and with their institution help to develop and keep industrial engineering current. In contrast, students identified a perceived lack of presence within their institutions of the quality assurance bodies such as the Engineering Council of South Africa and Southern African Institute of Industrial Engineers.

\subsubsection{Overall analysis of institutional (lecturers') responses}

The summary below of the analysis of institutional (lecturers') responses is based on a significant percentage response related to discussions held within the ambit of the literature review and the investigative sub-questions highlighted in the introduction to the study:

- Role of industrial engineering in industry: More than 75 per cent of the lecturers understand industrial engineering proficiently, and believe that it is a skill-based on knowledge and information on which industry can capitalise.

- $\quad$ Significance of industrial engineering in industry: 92 per cent of the lecturers agreed that industrial engineering plays a significant role in industry. Its responsibility in industry and background history is of great importance in influencing the South African economy. It is encouraging to note that only a negligible number disagreed with the above feedback. This reveals a strong awareness of industrial engineering as a pertinent component in economic growth and sustainability.

- Minimum skills level of a qualified graduate industrial engineer: 83 per cent of the lecturers agreed that a minimum requirement for industrial engineering in industry is a bachelor's degree and above. 
- Knowledge of the SAQA qualification framework for industrial engineering: 100 per cent of the lecturers were aware of, knowledgeable about, and understood the workings and interpretations of the National Qualification Framework and of industry expectations. Very encouraging is the 84 per cent of the lecturers who were in total agreement about the nature of student and industry expectations and about the importance of meeting this need.

\subsubsection{Effectiveness of lecturers:}

A significant 67 per cent of the lecturers agreed that they receive adequate teaching material from their institutions, possess effective teaching styles, and get support from their institution and from industry interactions that enhance the quality of the skills taught. It is important to note that 33 per cent of the lecturers feel inadequately supported in their personal capacity to teach industrial engineering, in responding to the statement, "I have the full support from my teaching and learning community". This personal inadequacy needs further investigation. This may possibly be due to the 66 per cent who disagree with the statement; "My current remuneration level is adequate given the work I do" (that is, for their lecturing services). The study further shows that lecturers significantly support discussion groups, family, and departmental interventions. 58 per cent of lecturers agree that their institution's interactions with the quality assurance bodies such as the Engineering Council of South Africa and the Southern African Institute of Industrial Engineers help to develop and keep industrial engineering current. An important fact noted in the statements is that 16 per cent of the lecturers do not believe that students have adequate access to industrial engineering information within their institutions' libraries. This small percentage may be due to inadequate or inaccessible South African industrial engineering literature at one institution as opposed to the total number of institutions sampled.

\subsubsection{Overall analysis of industry (SAIIE and ECSA) responses}

The following is a summary of the analysis of industry. The feedback is from a significant percentage response, related to discussions in the literature review and to the investigative sub-questions highlighted in the study:

- $\quad$ Role of industrial engineering in industry: 88 per cent of industry have an expert understanding of industrial engineering, and believe that it is a skill based on knowledge and information, on which industry can capitalise.

- Significance of industrial engineering in industry: 91 per cent of industry agreed that industrial engineering plays a significant role in industry, and its responsibility in industry is of great importance in influencing the South African economy. Of significance, however, is the 46 per cent of industry who are either uncertain about or do not know the significant historical role industrial engineering has played in the South African economy (compared with only 53 per cent of lecturers who agree that they know about this fact). The fact that 77 per cent of industry disagreed about an adequate awareness of industrial engineering in industry regionally may attest to the lack of knowledge of the history of industrial engineering in industry. It is encouraging to note that 55 per cent of industry believed that institutions contribute to skilling productive industrial engineers. However, 35 per cent are either uncertain or disagree with that statement.

- Minimum skills level of a qualified graduate industrial engineer: 82 per cent of industry agreed that a minimum requirement for industrial engineering in industry is a bachelor's degree and above. Industry is encouraging further development and research, as shown by the 94 per cent of individual industrial engineers either involved in, or pursuing, industrial engineering related projects and activities, showing a positive growth and advancement of industrial engineering knowledge and innovation in industry.

- Knowledge of the existing SAQA qualification framework for industrial engineering: More than 80 per cent of industry were aware of, knowledgeable about, and understood the workings and interpretations of the National Qualification Framework, and of what is expected of industry. 78 per cent of the industry agreed about the nature of student and industry expectations, and the importance of meeting this need. 


\subsubsection{Effectiveness of industry (SAIIE and ECSA):}

Only 49 per cent of lecturers agreed that institutions of higher learning receive adequate teaching material and possess effective teaching styles, including support from institution and industry interactions that enhance the quality of the industrial engineering skills taught. It is important to note that 29 per cent of industry and institutions of higher learning feel that there is adequate support for them in the research and development of industrial engineering. The other 70 per cent disagree, and feel that more should be done to develop industrial engineering research and development in industry and in institutions of higher learning. However, 89 per cent agree with the statement that industry is directly encouraged to develop industrial engineering, compared with the lecturers' views on this statement. 86 per cent of industry agree that there is potential for further growth in studies on industrial engineering. There is a 70 per cent industry agreement that the teaching environment creates a positive attitude in industrial engineering. 43 per cent of industry generally agrees that institutions of higher learning actively and positively participate with quality assurance bodies such as the Engineering Council of South Africa and the Southern African Institute of Industrial Engineers in monitoring and controlling the quality of industrial engineering education; notably, 56 per cent disagree with this. Industry generally agrees that interactions with the above-mentioned quality assurance bodies and with students at higher learning institutions are present to help develop and keep industrial engineering current.

\subsubsection{Quality effectiveness of industrial engineers}

The interrelationship between the three sectors of the quadrant highlights the following;

- the institutions' influence on the students' level of skills and knowledge acquisition in industrial engineering, and

- further demonstrates the interdependence between the students and industry in relation to the ability of the students to meet industry's expectations of their work ability, and

- the knowledge responsibility that the institution and the industry have in building and developing materials relevant for teaching skills needed by industry [33].

There is a relationship between the three groups (industrial engineering students, industrial engineering institutions of higher learning, and industrial engineering work industries). The effectiveness and efficiency model measured the gap between the three groups. The measure of effectiveness and efficiency depicted the level of value that students need to attain employability and value in industry. The inferences developed here categorise the three sample groups into two sectors of the four quadrants of the effectiveness and efficiency model. From the analysis, it is evident that industry and academia agree about being effective in the industrial engineering approach and being able to deliver this skill efficiently to the students. The students' 'fit' with Figure 6 falls within the effectiveness and inefficient quadrant ' $D$ ', as shown:

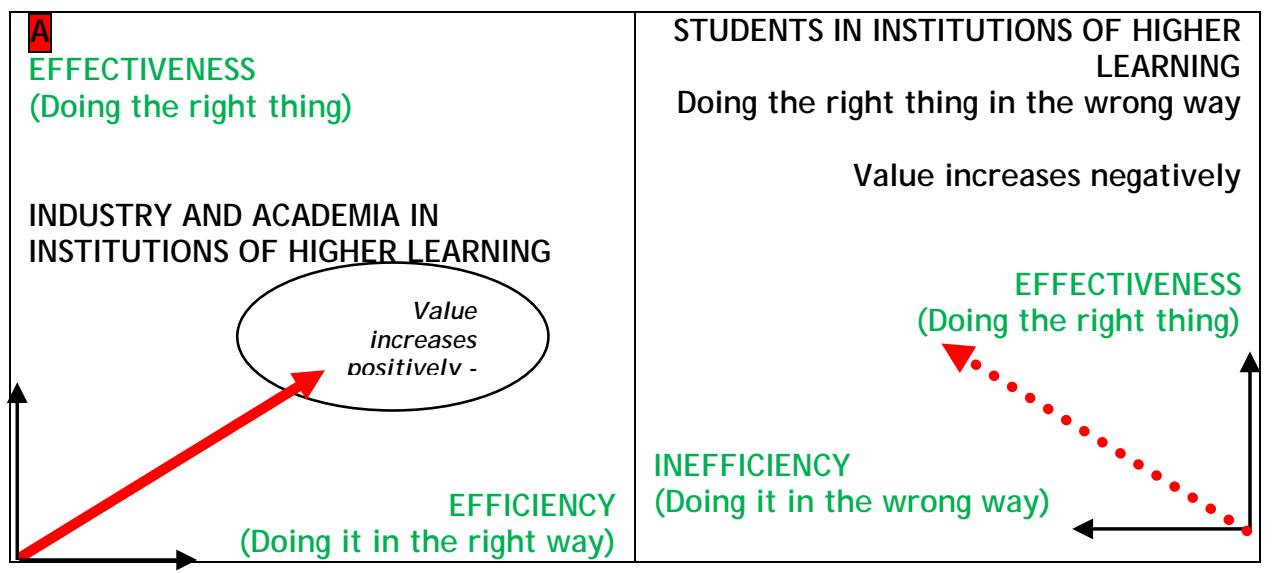

Figure 6: Efficiency and effectiveness: Value [14] 
It is thus evident from Figure 6 that students attain the necessary resources through their academic programmes and adequate interaction with industry, to be effective in applying the attained knowledge and skill in industry. However, how efficient the students are at using this skill to achieve this value in industry requires further research.

\subsection{Reliability testing}

A reliability measurement was conducted separately on every level of statements within the student, institution (lecturers'), and industry survey, based on the responses given in the scale. Table 2 lists the Cronbach's alpha coefficients determined for each sampled questionnaire. Tavakol and Dennick [34] indicate that Cronbach's alpha coefficients of 0.70 to 0.95 may be considered acceptable, but that lower values may be accepted in certain cases. Based on the tabulated information, the student, institution, and industry surveys show raw variable Cronbach's alpha coefficients of $0.979,0.974$, and 0.989 respectively, which indicate that the questionnaires were considered reliable.

Table 2: Cronbach's alpha coefficients for each sampled questionnaire

\begin{tabular}{|l|l|}
\hline Sample Questionnaire & Cronbach's alpha coefficient \\
\hline Student Survey & 0.979 \\
\hline Institution (Lecturer) Survey & 0.974 \\
\hline Industry Survey & 0.989 \\
\hline
\end{tabular}

\section{RECOMMENDATIONS AND CONCLUSION}

\subsection{Recommendations}

The inferences from the information gathered from the three surveys administered to the students, institutions, and industry bodies are as follows:

- $\quad$ Students have the right mindset about how effective industrial engineering is in adding value in industry, but are still limited in identifying with efficiency in applying the skill as far as 'best fit' is concerned. Efficiency in this case means the application of skills taught at institutions of higher education.

- Lecturers are adopting the right approach to teaching, motivating, and developing the industrial engineering skill. Furthermore, lecturers are demonstrating various ways of dynamically delivering the learning material by involving various facets of teaching, from practice to innovative theory.

- Industry fares well in its approach to developing skilled industrial engineering students in an effort to place industrial engineering at the forefront of South Africa's economic growth and sustainability. This is evident through its involvement in the growth of the practice and knowledge of industrial engineering. How this approach emerges is highly efficient, through the curriculum development advisory bodies, industry visits, and quality assurance audits managed by the various quality assurance bodies, as gleaned from the survey.

The following recommendation may address a solution to the inefficiency faced by the students:

- Embedding of total quality management principles in the learning process at universities: According to Ho and Wearn [7], the discussion of TQM as a management philosophy and company practice (in the literature review section), which aims to harness the human and material resources of an organisation in the most effective way to achieve the objectives of the organisation, refers to the principles and tools of total quality management as one way of managing institutions that provide industrial engineering as a learning programme. The opportunity is seen to develop valuable graduates by emphasising the human quality aspect as a resource that can be managed effectively, resulting in efficiency.

- A practical, hands-on approach plays a maj or role, as was highlighted by the industry survey in its expectations of academia in providing students with much-needed 
practical exposure, enabling them to decide on the most feasible approach to performing tasks in industry. It is increasingly difficult to draw a clear line around the discipline that is industrial engineering. Various generic skills that incorporate and apply a number of industrial engineering practices and skills (such as continuous improvement as a part of management practices, and newly created professions such as change managers, among others) have mushroomed over time. This has made industrial engineering a 'grey' discipline, creating more confusion among industrial engineering students. The need to clarify the role of industrial engineering within industry, such as through the inclusion of case study teaching methods in academia, which focus on the specific application of industrial engineering skills to specific problem areas, should be considered a priority.

- Developing and improving the students' motivation by instilling a deeper sense of camaraderie through the development of industrial engineering societies in the institutions, and building the students' knowledge of industrial engineering's background. This was highlighted by the students' survey, where students lacked the necessary direction and focal point at the start of their industrial engineering learning course.

\subsection{Conclusion}

The skills shortage remains a critical issue for South Africa. The study has, at some level, demonstrated the need to develop further innovative academic approaches that will produce better-equipped graduates. The study concludes with the following suggestions:

- Attaining value from students through the introduction of industrial engineering societies in institutions of higher learning. This will ultimately fuel interest and develop industrial engineering.

- $\quad$ Support lecturing staff and institutions of higher learning through research, knowledge development, and enterprising projects pertinent to current industry needs.

- Build on the current communication between the industry and institutions of higher learning through advisory boards, among other forums, by converting the current oneway feedback (industry to academia) into a two-way communication. That is. involve lecturers in the industry's decision-making process of company strategies.

- Influence institutions of higher learning to stimulate young minds in adopting application-based thinking approaches and enterprise-based methodologies. This will cultivate a productive business environment that will benefit all supply-chain stakeholders, and in so doing uplift the economy.

In order to remain competitive, industrial engineering aims to position itself as an innovator where overall value is the essence of performance, achieved through effective and efficient optimisation approaches.

\section{REFERENCES}

[1] Babbie, E. 2007. The practice of social research. 11 ${ }^{\text {th }}$ edition. Belmont (CA): Thomson Wadsworth.

[2] Burns, N. \& Grove, S.K. 2009. The practice of nursing research: Appraisal, synthesis, and generation of evidence. $6^{\text {th }}$ edition. St Louis (MO): Saunders Elsevier.

[3] Chikumba, S. (ed.). 2009. Impact of corporate strategy issues on industrial engineering core competencies and curriculum design. In: South African Institute of Industrial Engineers $22^{\text {nd }}$ Annual Conference, 28-30 October 2009, Gauteng, Roodevallei, 30-41.

[4] Cloete, N. (ed.). 2009. Responding to the educational needs of post-school youth: Determining the scope of the problem and developing a capacity-building model. Cape Town: Council for Higher Education and Training.

[5] Griesel, H. \& Parker, B., 2009. Graduate attributes: A baseline study on South African graduates from the perspective of the employers. Pretoria: Higher Education South Africa.

[6] Heitor, M., 2008. A system approach to tertiary education institutions: towards knowledge networks and enhanced societal trust. Science and Public Policy,35(8), 607-617.

[7] Ho, S.K. \& Wearn, K. 1996. A higher education TQM excellence model: HETQMEX. Quality Assurance in Education, 4(2), 35-42.

[8] Leedy, P.D. \& Ormrod, J.E. 2005. Practical research: Planning and design. $8^{\text {th }}$ ed. New J ersey: 
Pearson Education.

[9] Martin, R., Maytham, B., Case, J. \& Fraser, D. 2005. Engineering graduates' perceptions of how well they were prepared for work in industry. European J ournal of Engineering Education, 30(2), $167-180$.

[10] Mlambo-Ngcuka, P. 2006. Third Annual Julius Nyerere Memorial Lecture. Lecture presented at University of the Western Cape, Cape Town, South Africa. [Online]: http://www.dfa.gov.za/ docs/ speeches/ 2006/ mngcuk0906. htm. [Accessed: 26 February 2012]

[11] Moll, C.M. 1998. An engineering approach towards business transformation. Unpublished D Phil (Engineering) thesis. Faculty of Engineering. University of Pretoria.

[12] Nel, H. \& Mulaba-Bafubiandi, A.F. 2009. Key interventions in improving the throughput rate of Industrial engineering undergraduates: A case study at the University of Johannesburg. In: Industrial Engineering and Engineering Management, 8-11 December 2009, University of J ohannesburg, J ohannesburg, South Africa, 930-934.

[13] Nel, H. 2010. Future of engineering in South Africa. In: Bernadette Patricia Sunjka, Tomorrow's leaders conference, 18 March 2010, Sandton, J ohannesburg: Engineering Council of South Africa, 4.

[14] O'Sullivan, K. 2008. $5^{\text {th }}$ International Conference on Intellectual Capital, Knowledge Management and Organisational Learning: New York Institute of Technology, New York, USA, 9-10 October 2008. Academic Press.

[15] Project2010.co.za. 2007. Economic boom begins to bite. n.d. [Online] Available from: http:// www. project2010.co.za/2010_World_Cup_employment.asp?PN=15. [Accessed: 11 March 2012]

[16] SAllE. 2008. The changing role of industrial engineering in industry. In: South African Institute of Industrial Engineers $22^{\text {nd }}$ Annual Conference, 9 October 2008, Magaliesburg, Gauteng. 1-49.

[17] SAllE. 2013. SAllE Website. [Online] Available at: http://www.saiie.co.za/. [Accessed: 21 J anuary 2013]

[18] Siegle, D. 2012. Reliability calculator. [Online] Available at: http://www.gifted.uconn.edu/ siegle/ research/ instrument\%20reliability\%20and\%20validity/ reliability/ reliabilitycalculator2.xIs. [Accessed: 09 November 2012]

[19] South Africa. 1995. South African Qualifications Authority Act, No. 58 of 1995. Pretoria: Government Printers.

[20] South Africa. 2007a. The Presidency, Republic of South Africa. 2007. Accelerated and shared growth initiative for South Africa (ASGISA). Pretoria: Government Printers.

[21] South Africa. 2007b. The Presidency, Republic of South Africa. 2007. J oint initiative on priority skills acquisition (J IPSA). Pretoria: Government Printers.

[22] South Africa. 2007c. South African Qualifications Authority (SAQA), 2007. Trends in public higher education in South Africa: 1995 to 2004. Analysis of the National Learners' Records Database Report 2. Pretoria: Government printers.

[23] South Africa. 2007d. Industrial policy action plan (IPAP). Department of Trade and Industry, Pretoria: Government Printers.

[24] South Africa. 2008a. National Skills Development Act, No. 37 of 2008 (as amended). Pretoria: Government Printers

[25] South Africa. 2008b. National Qualifications Framework Act, No. 67 of 2008. Pretoria: Government Printer

[26] South Africa. 2008c. Statistics South Africa. Income and expenditure of households 2005/2006: Analysis of results. 2008, Vol. 22 February December 2008. Pretoria: Government Printers.

[27] South Africa. 2009b. Department of Home Affairs. 2009. White Paper on Immigration Act No. 13 of 2002: Specific professional categories and specific occupational classes. Notice 605 of 2009. Government Gazette, (32261):4, May 25.

[28] South Africa. 2009c. National industrial policy framework. Department of Trade and Industry, Pretoria: Government Printers.

[29] South Africa. 2010. Statistics South Africa. Bulletin of Statistics, 44(4) December 2010. Pretoria: Government Printers.

[30] South Africa. 2011b. Diagnostic Report (National Planning Commission). Department: The Presidency, Pretoria: Government Printers.

[31] South Africa. 2011c. Annual National Assessments. Department of Basic Education, Pretoria: Government Printers.

[32] South Africa. 2011d. Industrial policy action plan (IPAP). Department of Trade and Industry, Pretoria: Government Printers.

[33] Stevenson, W. 2008. Operations management: Theory and practice. Irvin, , McGraw-Hill.

[34] Tavakol, M. \& Dennick, R. 2011. Making sense of Cronbach's alpha. International J ournal of Medical Education, 2, 53-55.

[35] Wikipedia. 2013b. Total quality management. [Online] Available at: http://en.wikipedia.org/ wiki/Total_quality_management. [Accessed: 1 Dec 2012]

[36] Zandin, K.B. 2001. Maynard's industrial engineering handbook. New York, McGraw-Hill, 1.301.52 . 